DOI: $10.1515 /$ hssr -2017-0004

\title{
Convergence Between a New EU Economic Diplomacy and International Business Strategies
}

\author{
Nicoleta Vasilcovschi* \\ Jiangsu Xishan Senior High School, Wuxi, China
}

\begin{abstract}
Economic diplomacy is known as a symbol of the European Union and represents its primary function.

With the development of science and new ways of communication, the European Union can organize a new approach for its economic diplomacy. The main advantage of the European Union as a soft power is that its economic and diplomatic interests are represented in a manner that is based not on confrontation but economic collaboration with other states. The disadvantage is that this domain is presently not used enough to represent EU interests. This paper describes economic diplomacy in general and the economic diplomacy of the EU in particular. Divided into three parts, the goal of this study is to outline the importance of economic diplomacy, its evolution, the influence of this domain on the creation of previous economic treaties, and its possible future impact on the development of new agreements between the European Union and its neighbor countries.

The main methodology used is descriptive, presenting the evolution of this field and the new business strategies that can be used to improve cooperation at the eastern border of the European Union. Therefore we present here the historical background of EU economic diplomacy, its present issues and future challenges. The quantitative data used in this research paper are based on information from EU websites and on the actual events concerning debates about economic diplomacy and its future.
\end{abstract}

* PhD, Economics Lecturer for University of New South Wales (UNSW) Foundation and Advanced Placement (AP) at Jiangsu Xishan Senior High School, Wuxi, China; e-mail: wasnik2060@hotmail.com 
Nicoleta Vasilovschi, Convergence between a New EU....

HSS, vol. VI, no. 1 (2017): 52-61

The research questions presented herein follow the general evolution of this domain and its mutual influence with EU's businesses strategies.

Keywords

Economic diplomacy, Business strategies, Business diplomacy, European Union

\section{Introduction}

Economic interests and the emergence of new markets challenge countries to comport their economic diplomacies with new business strategies and develop novel areas of collaboration. The European External Action Service represents the European Union's external diplomacy as a whole, but the European Union's economic diplomacy is represented separately in every member state of the EU (Vasilcovski, 2012).

There is a need for the European Union to maintain strong economic diplomacy in order to represent the interests of its member states across the world. In order to understand how this domain will develop in the future and influence the Eastern Partnership of the European Union, one must first appreciate why the EU's economic diplomacy needs to be more active and practical while also understanding the role of European Union treaties which promote EU diplomacy and its economic interests. Therefore, a description of the European Union Diplomatic Service will be followed by details regarding its economic diplomacy structure and impact.

Unfortunately, the European Union's economic diplomacy is not analyzed and promoted enough in academic research. Economic diplomacy is never listed among the best promoted areas of academic research at the European Union level, yet this domain is more important for the promotion of the economic interests of the European Union than other domains that receive more recognition in the European community's research and development. On the other hand, businesses have their own promotion inside or outside the European Union. Therefore it is important to promote the interests of economic diplomacy with better-organized business strategies. 
If the European Union is interested in maintaining its dominant position in international trade, it can only be possible if economic diplomacy is combined and promoted with new business strategies of European firms and firms from other continents.

Additionally, sometimes economic diplomacy has influenced the creation and evolution of European treaties. According to Stephen Woolcock, the external trade illustrates how the EU Economic Diplomacy has evolved over time with progressive increase in the scope of EC/EU external trade policy, a trend that is formalized by the extension of the EU exclusive competence to all major trade issues and foreign direct investment in the Treaty of Lisbon (Woolcock, 2012: 12).

The advantages of European treaties include the fact that they are the EU's constitutional basis and every signatory state must follow their procedures.

So, economic diplomacy has long played a critical role in the evolution of several EU treaties and, resultantly, of the EU itself. Another important fact of the EU's economic diplomacy is its future impact on the geo-strategic partnerships of the European Union. International conditions have changed in recent years. In the past, political interests and economic interests were more divergent. In the interconnected economies of the world today, more and more ties have begun to develop between economic and political interests, necessitating a convergence of the two in order to maintain a balance of commercial and political forces at the international level.

\section{The importance of the EU's economic diplomacy and its evolution}

The primary novelty of new diplomacy is the inclusion of EU states promoting their own economic interests. The rise of globalization and the intensification of economic activities have made the European Union consolidate its diplomatic service in order to better represent its member states at the international level while also cultivating new areas of collaboration with other countries around the world.

The organization and consolidation of the European Union's general diplomacy was carried out at institutional level in 2009 with the creation of the European External Action Service. Upon inception of the Treaty 
of Lisbon, this function of the European Union was created with the role of officially representing the external policy of the European Union. Member states of the European Union contribute to the development of this goal and the abilities of the department overall in order to represent European Union interests globally. However, even if economic interests are the core of the European Union, there is not yet a unique representative department of the European Union's economic diplomacy but, rather, a situation in which every member state has its own arm for economic diplomacy. Therefore, if we speak about the evolution of economic diplomacy in the European Union, we must sum the interests of its twenty-eight member states in order to find common economic interests and then derive an appropriate plan of action for the European Union altogether.

In order to consolidate the future of its economic diplomacy, especially after Brexit, it is the moment for the European Union to promote more research and development in this domain as well as the activity of local businesses abroad. It can also use new business strategies to compete at the international level in order to maintain its dominant position in international commerce. This measure can attract more consumers if, for example, a perfectly competitive market structure like pure competition will adopt the European example concerning agriculture and bio products. Worldwide consumption is adapted to modern demand, and so European Union products can be promoted more in Asia - especially in China, where consumption has boomed in the last ten years. According to Yves Buchet de Neuilly, the goal of EU's external policy is to promote internal cooperation while also developing external economic relations through diplomatic representation (Buchet de Neuilly, 2005: 5).

The most recent debates on the economic diplomacy of the European Union were held in Brussels in February 2016. The discussion demonstrated the importance of this domain for the modern economy of the European Union and its sustainable development ${ }^{1}$

Although the discussion in the Brussels meeting presented the general goals of economic diplomacy, these discussions remain too broad and their conclusions should concentrate more on economic and diplomatic research for the coming years. This issue is why the key research 


\section{HSS, vol. VI, no. 1 (2017): 52-61}

question of this paper is to discover whether the European Union can create a new economic diplomacy based on a stronger connection between business strategies at the community level and the goals of EU diplomacy. The promotion of its economic diplomacy ought not to be only through general representation of member states but also through European companies which can expand at the international level while simultaneously representing the EU's economic goals. In all, the EU should create a research platform in the field of economic diplomacy in order to give a forum to diplomats, scholars, and business practitioners in which to interact and share their ideas.

\section{Main European treaties and their goals}

Two treaties at the core of the European Union are The Treaty on the Functioning of European Union, signed in Rome in 1958 which established the European Economic Community, and The Treaty on European Union, signed in Maastricht in 1992. These two agreements form the basis of the European Union's structure, thereby influencing the creation of other treaties between the EU and its member states. From the beginning, the European Union started as an economic community representing the economic interests of its member states. Therefore, from its inception one of the EU's primary functions has been the promotion of economic diplomacy.

The major advantage of economic diplomacy is that member states can benefit from their collaboration within the European Community. For example, the first three European Communities - the European Atomic Energy Community (EURATOM), the European Coal and Steel Community (ECSC), and the European Economic Community (EEC) had their roots in economic diplomacy goals and European business strategies. The ECSC expired in 2002 but EURATOM and the EEC are still in force today. Also, another treaty which had its basis in economic diplomacy is The First Budgetary Treaty (Luxembourg) and The Second Budgetary Treaty (Brussels), both of which remain in force. The main goals of the EU as a member of the World Trade Organization (WTO) are: the opening of new markets for European firms, the requirement that firms follow fair competition rules, and the promotion of sustainable development of trade. ${ }^{2}$ 


\section{HSS, vol. VI, no. 1 (2017): 52-61}

One important sector of EU with high costs but also an increase in its production is agriculture. On May 23, 1992, the EU reformed its Common Agricultural Policy (CAP) so that - in accordance with 1999's "Agenda 2000" reforms - it was divided into two sections: market support and rural development. Dacian Ciolos considers that the CAP has to keep these two pillars of the agreement but must also adapt to the challenges of an increasingly interconnected world through sustainable production in order to ensure global food security, more research and development, sustainable management of natural resources, market management instruments, sustainable and inclusive growth in rural areas, and shared experience in rural development. ${ }^{3}$ First of all, a modern agriculture can increase EU production and can also attract foreign investment and opportunities for the creation of small-to-medium companies. Secondly, the consumption of bio-products can increase the demand for these goods and, in turn, will create opportunities for more European firms to be in the market. Thirdly, this sector can contribute to the improvement of economic diplomacy strategies and their effect worldwide. For example, "In ten years, the total (fully converted and inconversion organic area) would have increased from 5.7 million ha to an estimated 9.6 million ha ( $+6 \%$ per year) for the EU-27."4

Member states of the EU realize that without strong economic diplomacy, it will be difficult to compete in the global market. In this context of "new growth paradigm", the EU has to develop a strategy including main economic, political and business objectives of its member states.

One first step is to create free trade and investment agreements, followed by unilateral economic or trade measures, economic sanctions. Another step is to enforce the impact from EU for the international development programs ${ }^{5}$.

Using the function of economic diplomacy to promote open door diplomacy and its economic interests domestically and abroad, the EU community gives the opportunity to its members to enjoy access to new markets, provide a platform for sustainable economic development, and ensure food security. 
Nicoleta Vasilovschi, Convergence between a New EU....

HSS, vol. VI, no. 1 (2017): 52-61

\section{A theoretical approach on the convergence between EU businesses and economic diplomacy for the future of EU Eastern Partnership}

International stability is the question that is central to the future of the European Union Eastern Partnership. Unlike in the past, when technological and scientific advances started to blossom, today's emphasis on consumption and speed has changed the lifestyle of many Europeans. Economic diplomacy must be adapted to the new business strategies of European firms.

A business strategy represents a plan designed for the long term in order to achieve a central goal or a set of objectives. Business diplomacy is the representation of the company and its subsidiaries worldwide. Managers coordinate business diplomacy through the organization of strategies and goals, the use of bilateral and multilateral negotiations, the creation of international public relations campaigns (Saner et al, 2000: 13), and the collection and analysis of economic data about the host country's economic situation and investment perspectives.

Presently, businesses do not have to bear as much pressure in their production process as in the past. Some new rules and policies should be implemented to solve management problems and adapt business strategies to the vision of Europe's economic diplomacy.

The Eastern Partnership (EaP) represents a collaboration between EU and its member states and six Eastern European countries: the Republic of Moldova, Ukraine, Georgia, the Republic of Belarus, the Republic of Azerbaijan and the Republic of Armenia.

The partnership includes different international values from the principles of international law to support for the development of a market economy.

The Joint Declaration of the Eastern Partnership Summit (Riga, 21-22 May 2015) sketches also the main values of economic cooperation between $\mathrm{EU}$ and its six Eastern states partners, insisting on the improvement of macroeconomic stability and the business environment, also on the promotion of trade, growth and competitiveness. This is the main goals to be achieved in order to maintain security, stability and economic development in EU and in the Eastern neighboring countries. ${ }^{6}$ 
Having been influenced by the trend of economic diplomacies of its member states, European economic diplomacy maintaining its unique structure according to the economic development of EU members, can influence the development of economic partnership for EaP members countries.

Not only that, important changes in EU economic diplomacy will keep a stable environment for business in the European community. Also, the promotion of European business strategies worldwide may have the highest impact in providing more information regarding the development of the purely competitive market structure of agriculture, monopolistic competitive market structure, oligopolistic market structure, or monopolistic market structure in different industries and areas of the world.

All these economic changes may influence positively the political stability of Europe in the coming years. Therefore, the use of business strategies not only to promote European businesses abroad but also to create new opportunities for European Union partnerships is a central axis of future development for the European Union's Eastern and international partnership.

\section{Conclusions}

The European Union was, is, and maybe will continue to be a group of countries with common economic goals whose soft power can be heightened further with a diverse application of business strategies. The emergence of new economies on the international level represents a challenge for the European Union. Therefore, a stronger correlation between economic diplomacy and business strategy can maintain the political and economic stability of the EU and can improve the collaboration between the EU and other countries across the world. The EU has a strong economic diplomacy and, by using a mix between its economic diplomacy and the business diplomacy of European companies, it can increase its export of a variety of products including organic goods.

There is a need for the EU to encourage more research in the realm of economic diplomacy. By learning more in this field, the experts of the future will have a better understanding of it and will be up to date with 


\section{HSS, vol. VI, no. 1 (2017): 52-61}

new developments in business strategy. So, the popularity of economic diplomacy can help cultivate new areas of research in this field - which should promote greater transparency - and also can increase access for non-member countries to the European business environment.

With the use of its economic diplomacy function to create both diplomatic and economic opportunities, the EU gives its member states and their businesses the chance to share their experience and strategies with non-member states. Also there is the opportunity for the companies from these states to compete and collaborate in the global market while also creating a sustainable partnership for the business strategies of the future.

\section{References}

Buchet de Neuilly, Y. (2005) L'Europe de la politique étrangère. Paris : Ed. Economica.

Ciolos, D. (2010). I want a CAP that is strong, efficient and well balanced, available at http://europa.eu/rapid/press-release_SPEECH-10-400_en.htm?locale=en

Saner, R., L.Yiu, M. Sondergaard (2000). Business Diplomacy Management. A Core

Competency for Global Companies, Business Diplomats, Academy of Management Executive, vol. 14(1). 80- 92. February 2000. 1-28.

Vasilcovschi, Nicole (2012) "Diplomatia economica si provocarile globalizarii”, Constanta: Fundatia Andrei Saguna Publishing.

Woolcock, S. (2012). European Union Economic Diplomacy, The Role of the EU in the External Economic Relations, Ashgate.

Economic Diplomacy and Foreign Policy: Friends or Foes, European Commission, Brussels, 25 February 2016, available at http://ec.europa.eu/epsc/events/ detail/2016-02-25-economic-diplomacy_en.htm

EU \& WTO. (2009) http://ec.europa.eu/trade/creating-opportunities/euand-wto/

Facts and figures of organic agriculture in the European Union, p.9, October 2013, available at http://ec.europa.eu/agriculture/markets-and-prices/morereports/pdf/organic-2013_en.pdf

EU Foreign Economic Diplomacy, April 2016, available at https://www. businesseurope.eu/sites/buseur/files/media/position_papers/rex/foreign_ economic_diplomacy-_final.pdf

Joint Declaration of Eastern Partnership Summit (2015) http://eeas.europa.eu/ eastern/docs/riga-declaration-220515-final_en.pdf. 
${ }^{1}$ Economic Diplomacy and Foreign Policy: Friends or Foes, European Commission, Brussels, 25 February 2016 http://ec.europa.eu/epsc/events/detail/2016-0225-economic-diplomacy_en.htm

${ }^{2}$ EU \&WTO, http:/ / ec.europa.eu/trade/creating-opportunities/eu-and-wto/ (2009).

${ }^{3}$ Dacian Ciolos, I want a CAP that is strong, efficient and well balanced, http://europa.eu/rapid/press-release_SPEECH-10-400_en.htm?locale=en (2010)

${ }^{4}$ Facts and figures of organic agriculture in the European Union, p.9, October 2013, available at http://ec.europa.eu/agriculture/markets-and-prices/more-reports /pdf/organic-2013_en.pdf

5 EU Foreign Economic Diplomacy, April 2016, available at https://www. businesseurope.eu/sites/buseur/files/media/position_papers/rex/foreign_ec onomic_diplomacy-_final.pdf

${ }^{6}$ Joint Declaration of Eastern Partnership Summit (2015) http://eeas.europa.eu/ eastern/docs/riga-declaration-220515-final_en.pdf.

\section{Biographical note}

Nicoleta Vasilcovschi is a Romanian PhD Economics Lecturer and writer. She taught Economics for the last three years in China. She has written three academic books, on business communication and on economic diplomacy and globalization, and is a collaborator with Radio Iasi. For fifteen years, Nicoleta Vasilcovschi was member of different NGOS from Romania, supporting their activities. Last year she was the President of First Bilingual Wuxi Toastmasters Club, China, helping the members of her club to improve their public speaking skills. 